\title{
Foxed intra- and interspecific differentiation in Leptogorgia (Octocorallia: Gorgoniidae). A description of a new species based on multiple sources of evidence
}

\author{
M. Mar Soler-Hurtado 1,2,3, César Megina ${ }^{2}$, Annie Machordom ${ }^{1}$, Pablo J. López-González ${ }^{2}$ \\ ${ }^{1}$ Dpto. Biodiversidad y Biología Evolutiva, Museo Nacional de Ciencias Naturales, CSIC, 28006 Madrid, Spain. \\ (MMS-H) (Corresponding author) E-mail: mar.s.hurtado@mncn.csic.es. ORCID-iD: http://orcid.org/0000-0002-0284-9900 \\ (AM) E-mail: annie@mncn.csic.es. ORCID-iD: http://orcid.org/0000-0003-0341-0809 \\ ${ }^{2}$ Biodiversidad y Ecología de Invertebrados Marinos, Facultad de Biología, Universidad de Sevilla, 41012, Sevilla, Spain. \\ (CM) E-mail: cmegina @us.es. ORCID-iD: http://orcid.org/0000-0002-9462-9330 \\ (PJL-G) E-mail: pjlopez@us.es. ORCID-iD: http://orcid.org/0000-0002-7348-6270 \\ ${ }^{3}$ Instituto Nacional de Biodiversidad, Museo Ecuatoriano de Ciencias Naturales. Rumipamba 341 y Av. Shyris, Quito, \\ Ecuador.
}

\begin{abstract}
Summary: The challenges of delimiting and identifying marine invertebrate species impede estimations of true biodiversity. This is particularly true in the case of gorgonian diversity, in which only classical morphological characters (e.g. branching pattern, size and colouration of the colony and sclerites, etc.), which can be homoplastic and continuous, have been used. In this study, using an integrative taxonomic approach, we analysed two morphs initially considered as two eco-typical variants of Leptogorgia alba Duchassaing and Michelotti, 1864, living sympatrically in the littoral area of Ecuador. We explored the use of classical morphological and morphometric characters to delimit species in combination with the analyses of molecular markers (mtMutS, CoxII-Igr-CoxI, ITSs, and 28S rRNA) to infer phylogenetic relationships. Based on our results, two species should be considered, L. alba and a new species, L. manabiensis $\mathrm{n}$. sp., which showed distinguishing morphological features that cannot be attributed to phenotypic plasticity. Both species also showed significant differences in morphometric, non-correlated characters in all size classes. The phylogenetic analyses showed a polyphyletic L. alba-L. manabiensis n. sp. species complex, and ancestral polymorphism and incomplete lineage sorting as possible evolutionary processes leading to this pattern. In conclusion, the combination of morphological and morphometric evidences provides the best support for the identification and delimitation of these challenging species. In addition, molecular analyses, mainly supported by nuclear markers, allow fundamental aspects of the evolutionary history of these organisms to be discerned.
\end{abstract}

Keywords: incomplete lineage sorting; hybridization; ITS; mtMutS; 28S; CoxII-Igr-CoxI; Igr; Ecuador.

Diferenciación intrincada intra- e interespecífica en Leptogorgia (Octocorallia: Gorgoniidae). Descripción de una nueva especie en base a distintas fuentes de evidencias

Resumen: Las dificultades existentes en la delimitación e identificación de especies de invertebrados marinos, impiden estimar la verdadera biodiversidad. Esto es particularmente observable en el caso de estudios sobre la diversidad de gorgonias, en los que tradicionalmente sólo se han utilizado caracteres morfológicos (por ejemplo, patrón de ramificación, tamaño y coloración de la colonia y escleritos, etc.) que pueden ser homoplásicos y continuos. En este estudio, utilizando un enfoque basado en una taxonomía integradora, se analizaron dos morfologías inicialmente consideradas como dos variantes eco-típicas de la especie Leptogorgia alba Duchassaing y Michelotti, 1864, ambas viviendo simpátricamente en el litoral de Ecuador. Exploramos el uso de caracteres morfológicos clásicos y morfométricos para delimitar especies, en combinación con marcadores moleculares (mtMutS, CoxII-Igr-CoxI, ITSs y 28S rRNA), con el objetivo de inferir sus relaciones filogenéticas. En base a nuestros resultados, se debe considerar la existencia de dos especies, $L$. alba y una nueva especie, L. manabiensis n. sp. que muestran caracteres morfológicos distintivos que no son atribuibles a la plasticidad fenotípica. Ambas especies también presentaron diferencias significativas en los caracteres morfométricos analizados, no correlacionados, en todas las clases de tamaño. Los análisis filogenéticos mostraron un origen polifilético del complejo de especies L. alba - L. manabiensis $\mathrm{n}$. sp., a partir de un polimorfismo ancestral y una separación incompleta de los linajes, como posibles procesos evolutivos conducentes al patrón observado. En conclusión, la combinación de evidencias morfológicas y morfométricas proporcionan el mejor apoyo para la identificación y delimitación de estas especies. Además, los análisis moleculares, apoyados principalmente por marcadores nucleares, permiten discernir aspectos fundamentales de la historia evolutiva de estos organismos.

Palabras clave: resolución incompleta de linajes; hibridación; ITS; mtMutS; 28S; CoxII-Igr-CoxI; Igr, Ecuador.

Citation/Como citar este artículo: Soler-Hurtado M.M., Megina C., Machordom A., López-González P.J. 2017. Foxed intra- and interspecific differentiation in Leptogorgia (Octocorallia: Gorgoniidae). A description of a new species based on multiple sources of evidence. Sci. Mar. 81(2): 147-157. doi: http://dx.doi.org/10.3989/scimar.04509.01C 
LSID: urn:1sid:zoobank.org:pub:2A57A79C-2085-42FD-B947-62456AB87C13

Editor: X. Turon.

Received: July 13, 2016. Accepted: March 13, 2017. Published: April 27, 2017.

Copyright: (C) 2017 CSIC. This is an open-access article distributed under the terms of the Creative Commons Attribution (CC-by) Spain 3.0 License.

\section{INTRODUCTION}

In the last decade, several studies have highlighted the difficulties of identifying marine species, especially invertebrates, using only morphological characters (Calvo et al. 2009, López-González et al. 2015, Alfaya et al. 2015), which can lead to an underestimation of biodiversity, and possibly adversely impact the conservation of endangered species or those with restricted distributions (see e.g. Rocha-Olivares et al. 2001, Dincă et al. 2011, Eberle et al. 2016).

Understanding species boundaries in corals, particularly in octocorals, is a challenge for several fields of study, including taxonomy, evolutionary biology, life history and ecology (Vermeij et al. 2007, Stefani et al. 2008, Gori et al. 2012). The identification of octocorals has traditionally relied on morphological features (from the seminal studies of Bayer et al. 1983, Breedy and Guzman 2003, Vargas et al. 2010); however, this is often problematic as some features are homoplastic (Sánchez and Wirshing 2005, Sánchez et al. 2007, Gori et al. 2012). Moreover, morphometric analyses have shown that the observed overlapping range for some continuous characters in octocorals is widely attributed to an apparent phenotypic plasticity, making consistent taxonomic units difficult to establish (Weinbauer and Branko 1995, Sánchez 2009). Evolutionary processes, such as interspecific hybridization, explosive radiation and incomplete lineage sorting (Hatta et al. 1999, Vollmer and Palumbi 2004, Forsman et al. 2010), may also contribute to the difficulty of distinguishing closely related species.

Although molecular studies of octocorals have been performed, resolution at the species level is not always observed, such as in the genera Pacifigorgia, Leptogorgia and Eugorgia (Vargas et al. 2014, Ament-Velásquez et al. 2016), and the Alcyonium species complex (McFadden and Hutchinson 2004), or even at the genus level, as in Plexaura, Pseudoplexaura, Eunicea and Eunicella, for instance (Sánchez et al. 2003, McFadden et al. 2006, Gori et al. 2012, Costantini et al. 2016). Based on the idea that "more is better" (Winkler et al. 2015), many authors have supported the use and concatenation of nuclear and mitochondrial markers, such as ITSs (internal transcribed spacers ITS1 and ITS2), 28S rRNA, mtMutS and Cox (partial Cox-II and I including the Igr1 region) (McFadden et al. 2006, 2011, Aguilar and Sánchez 2007, Sánchez et al. 2007). In addition, anthozoan mitochondrial genomes, especially those of octocorals, evolve 10 to 100 times more slowly than those of other metazoans (France and Hoover 2002, McFadden et al. 2004, Hellberg 2006), and possible incongruences between mitochondrial and nuclear phylogenetic reconstructions may be attributed to hybridization.
Methodological advances in morphological analysis, such as the use of morphometric statistics, can provide additional characteristics regarding the shape and structure of organisms (Gori et al. 2012). These techniques may better delimit difficult cases of species identification, reducing possible taxonomist subjectivity (Mutanen and Pretorius 2007) and molecular conflicts. Furthermore, these analyses have been shown to be at least as accurate as classical morphological and phylogenetic analyses in the delimitation of closely related species such as between Eunicellla singularis morphotypes (Gori et al. 2012), and within the Choristoneura fumiferana species complex (Lumley and Sperling 2010) and Ophion scutellaris (Thomson species group) (Schwarzfeld and Sperling 2014).

In other ecosystems, combining analyses has provided a stronger evaluation of species identification (Schwarzfeld and Sperling 2014). Thus, an integrative taxonomic approach is likely best for understanding octocoral benthic community diversity (Dayrat 2005, Padial et al. 2010, Pérez et al. 2016).

Using such an approach, we investigated two Ecuadorian morphotypes of the genus Leptogorgia MilneEdwards and Haime, 1857, which is considered one of the most cosmopolitan genera of the Gorgoniidae family (Grasshoff 1988, Breedy and Guzman 2007, Soler-Hurtado and López-González 2012). Specifically, these two morphs may represent eco-typical variants of Leptogorgia alba Duchassaing and Michelotti, 1864 , or they may constitute two distinct species coexisting in the same habitat. With more than 60 valid species (Williams and Chen 2012), Leptogorgia is widely distributed in the Mediterranean and Caribbean seas, Atlantic and Pacific oceans, and South African and sub-Antarctic coasts (Bayer 1961, Grasshoff 1988, Williams and Chen 2012). In the eastern Pacific, Leptogorgia is one of the most frequently encountered genera (in terms of species richness and abundance), with 27 described species known for this area (Breedy and Guzman 2007, Horvath 2011, Soler-Hurtado and López-González 2012). Leptogorgia species are generally restricted to shallow-water habitats (although Leptogorgia styx Bayer, 2000, has been found at a depth of $1900 \mathrm{~m}$ at the East Pacific Rise) and are distinguished from each other based on a few characters including the colour of the colony, branching patterns (filiform, dichotomous, or pinnate), the absence of anastomosis (in most cases), the polyp mound, and coenenchymal sclerites (spindles and captans) (Bayer et al. 1983, Grasshoff 1988, Breedy and Guzman 2007).

Here, we report our analyses of the morphological and genetic variation of two Leptogorgia alba Duchassaing and Michelotti, 1864 morphs, using molecular analyses and classical morphology, with the support of 

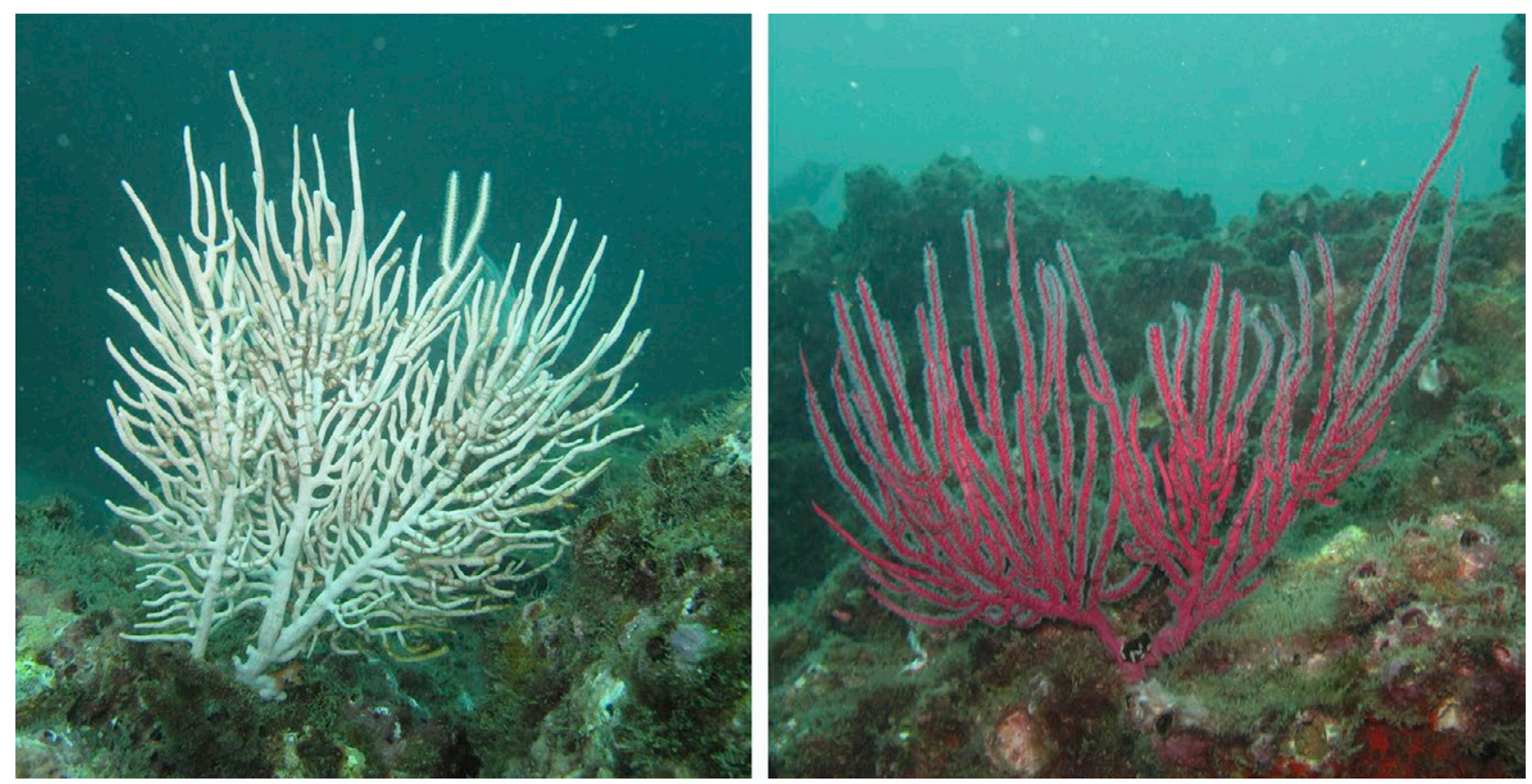

Fig. 1. - Underwater images of the two Ecuadorian morphs collected in Los Frailes, Machalilla National Park (Ecuador), where L. alba (white, left) and L. manabiensis n. sp. (pink, right) were observed at a sympatric location (side by side).

morphometric techniques, to determine whether they represent a single species or distinct species. This study contributes towards understanding the relationship between genetic and morphological variation in this case study.

\section{METHODS}

\section{Sampling}

Leptogorgia colonies were collected by SCUBA diving from rocky bottoms in Machalilla National Park (Manabí, Ecuador), which is considered one of Ecuador's most important marine-terrestrial reserves. Sampling was performed between February 2010 and June 2014. We collected 40 colonies from each of the two morphs of Leptogorgia. The attachment at the base of the holdfast with coenenchyme was left in place so that the colony could have the possibility to regenerate following collection. Growth plasticity and growth rates in closely related shallow-water species and genera are faster than initially suspected (e.g. Rossi et al. 2011, Viladrich et al. 2016). These morphs are among the most common gorgonians at 3-30 $\mathrm{m}$ depth in the littoral zone of Ecuador. Given the uncertainty in their species status, they are of special interest for conservation management.

To account for the high range of size variability, colonies were collected according to four size classes, determined by the distance between the holdfast and the most distant branch tip (class $1, \leq 70 \mathrm{~mm}$; class 2, between 71 and $140 \mathrm{~mm}$; class 3 , between 141 and 210 $\mathrm{mm}$; and class $4,>211 \mathrm{~mm}$ ).

Photographs of the sampled specimens were first taken underwater (Fig. 1) and then again on deck. Subsamples were either stored in absolute ethanol for molecular analysis or in $4 \%$ buffered formalin (after relaxation with menthol crystals) for morphological analysis. Formalin-fixed subsamples were subsequently transferred to $70 \%$ ethanol until analysis. The remaining colonies were air dried.

Collected specimens were deposited in the Museo Ecuatoriano de Ciencias Naturales (MECN), the octocoral reference collection of the research group "Biodiversidad y Ecología de Invertebrados Marinos" at the University of Seville (BEIM), the Museo Nacional de Ciencias Naturales in Madrid (MNCN-CSIC) or the Museu de Ciénces Naturals in Barcelona (MZB).

\section{External morphology and SEM study}

Colony fragments were prepared for scanning electron microscopy (SEM) according to standard methods (Bayer and Stefani 1989, Alderslade 1998). Additionally, permanent mounts were prepared for light microscopy observation. The colonies were described and illustrated according to standard terminologies (Bayer et al. 1983, Breedy and Guzman 2007).

\section{Morphometry of the colonies}

For each colony, the total area and total area without gaps were measured (Fig. 2) using the ImageJ software (Java version of NIH image) (Abràmoff et al. 2004), calibrated using a ruler as a reference.

The following measurements were taken from each colony: maximum height, maximum width, and average and maximum lengths of the primary branches. The number of ramifications and the number of branches of each order were also counted.

The following colony parameters were measured and calculated: mean width (mean of three measurements, taken at equidistant positions at a right angle to the height) (Gori et al. 2012); height to width ra- 

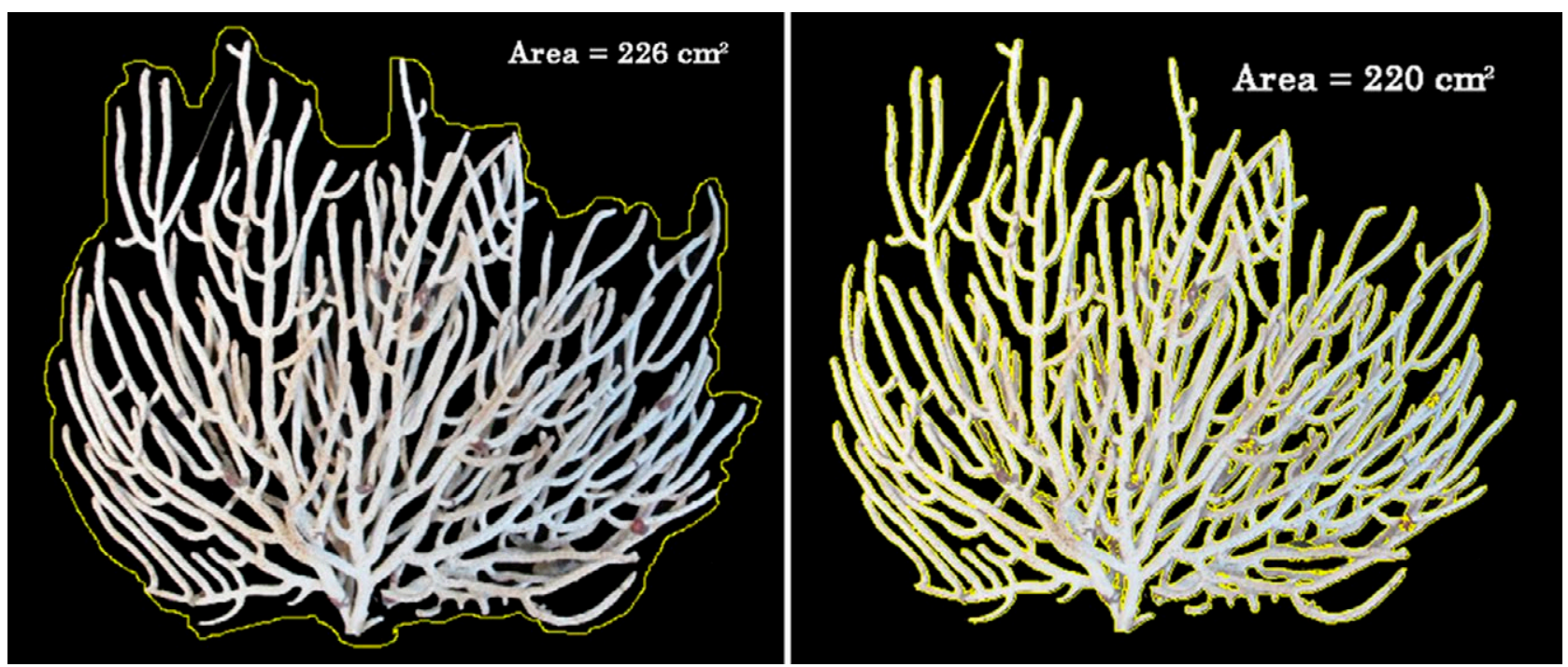

Fig. 2. - Images showing the differences between total area of the colony (left) and area without gaps (right).

tio; height to mean width ratio; ramification density (number of ramifications per surface area using both total area and area without gaps) (Weinbauer and Branko 1995); order of the colony [using a methodology developed by Horton (1945) and later modified by Strahler (1954)]; mean length of the primary branches; maximum length of the primary branches to maximum height ratio; tributary to source ratio of primary and secondary order branches (T/S) ("tributaries" (T) are branches that join branches of higher order (i.e. no change in order), and "sources" (S) are branches that join branches of equal order) (Brazeau and Lasker 1988); bifurcation ratio (the ratio of the number of branches of a given order to the number of branches of the next higher order) (Horton 1945, Strahler 1954, Brazeau and Lasker 1988); main thickness of the primary, secondary and tertiary order branches; angle formed between primary and secondary order branches; angle formed between secondary and tertiary order branches; and angle formed by basal branches with respect to the central axis.

\section{Morphometric statistical analyses}

As two highly collinear variables contain the same information and would be redundant for the purpose of analysis (Anderson et al. 2008), we checked for correlations among the morphometric variables measured, prior to modelling. Only variables having absolute inter-correlation values of less than 0.75 were subsequently used. The data were organized into a morphometric variable/sample matrix, and an Euclidean distance similarity matrix was calculated based on the normalized data (Anderson 2001). Differences in the multivariate structure were analysed in a distance-based permutational multivariate analysis of variance (PERMANOVA) (Anderson 2001, McArdle and Anderson 2001). The experimental design included two crossed fixed factors: morph (with two levels) and size (with four levels). The sum of squares (SS) used was Type III
SS, where every term in the model is fitted only after taking into account all other terms in the full model (Anderson et al. 2008). We used 9999 permutations of residuals under a reduced model (Anderson 2001). Homogeneity of dispersions was also tested with the PERMDISP routine, which performs a Levene-type test using the group means but obtains the p-values by permutations (Anderson 2006). Multivariate analyses were performed using the software PRIMER v6.1.11 \& PERMANOVA v1.0.1 statistical package (Clarke and Gorley 2006).

\section{DNA extraction, PCR amplification and sequencing}

Genomic DNA was extracted from 20-30 mg of tissue using the DNeasy extraction Kit (Qiagen, Inc.), according to the manufacturer's protocol. Amplifications were carried out in $50 \mu \mathrm{L}$ final volume reactions containing $5 \mu \mathrm{L}$ of $10 \times$ buffer (containing $10 \times 2 \mathrm{mM}$ $\left.\mathrm{MgCl}_{2}\right), 1 \mu \mathrm{L}$ dNTPs mix $(10 \mathrm{mM}), 0.8 \mu \mathrm{L}$ of each primer $(10 \mu \mathrm{M}), 0.5 \mu \mathrm{L}$ of Taq DNA polymerase $(5 \mathrm{U} /$ $\mu \mathrm{L})$ (Biotools) and $2 \mu \mathrm{L}$ of genomic DNA. Cycling parameters and primer combinations used for each marker are given in Table 1. The amplicons were sequenced for both strands using BigDye Terminator in an ABI 3730 genetic analyser (Applied Biosystems). Sequences were edited using Sequencher v.4.6 (Gene Code Corporation, Ann Arbor, MI, USA).

The molecular data matrix consists of sequences from species reported here and from other recently sequenced species including E. ahorcadensis SolerHurtado and López-González, 2012, E. daniana (1 and 2) Verrill, 1868, L. diffusa Verrill, 1868, L. obscura Bielschowsky, 1929, L. mariarosae Soler-Hurtado and López-González, 2012 and P. stenobrochis Valenciennes, 1846 (Table 2). For Antillogorgia bipinnata (= Pseudopterogorgia bipinnata), the following GenBank sequences were used: mtMutS (GQ342499), Cox (GQ342423), ITS (EU043125), and 28S (JX203712), and other recently sequenced species (Table 2). 
Table 1. - Primers and PCR conditions used to amplify fragments of nuclear and mitochondrial genes in the studied Leptogorgia species. In the PCR protocol column, we indicate annealing temperature, time in seconds for the denaturation (at $94^{\circ} \mathrm{C}$ ), annealing and elongation (at $72^{\circ} \mathrm{C}$ ), respectively, and the number of cycles for each gene, independent of the primer combination used. *PCRs were performed with the following primer combinations: Cox: $1+3$, or $1+4$ and $2+3$; mtMutS: $5+6$; ITSs: $7+8$; 28 S rRNA: $9+10$ or 9+11.

\begin{tabular}{|c|c|c|c|c|c|}
\hline & Primer & Code* & * Sequence & Reference & PCR protocol \\
\hline \multirow[t]{4}{*}{ Cox } & COII $8068 \mathrm{~F}$ & 1 & 5'-CCATAACAGGACTAGCAGCATC-3' & McFadden et al. 2004 & \multirow[t]{4}{*}{$58^{\circ} \mathrm{C} 45: 60: 60 \times 40$} \\
\hline & COI- Gorg2-F2 & 2 & 5'-GATTCGGAAATTGGTTTGTG-3' & Present paper & \\
\hline & COIOCTR & 3 & 5'-ATCATAGCATAGACCATACC-3' & France and Hoover 2002 & \\
\hline & COI-Gorg1-R3 & 4 & 5'AGAGAAGGTGGTAATAACCAGAAA-3' & Present paper & \\
\hline \multirow[t]{2}{*}{ mtMutS } & ND42599F & 5 & 5'-GCCATTATGGTTAACTATTAC-3' & France and Hoover 2002 & \multirow{2}{*}{$58^{\circ} \mathrm{C} 90: 90: 60 \times 35$} \\
\hline & MUT3458R & 6 & 5’-TSGAGCAAAAGCCACTCC-3' & Sánchez et al. 2003 & \\
\hline \multirow[t]{2}{*}{ ITSs } & ITS 2.1 & 7 & 5’CGTAGGTGAACCTGCGGAAGGATC-3’ & Hugall et al. 1999 & \multirow[t]{2}{*}{$56^{\circ} \mathrm{C} 60: 90: 60 \times 35$} \\
\hline & ITS 2.2 & 8 & 5'-CCTGGTTAGTTTCTTTTCCTCCGC-3' & Hugall et al. 1999 & \\
\hline \multirow[t]{3}{*}{$28 \mathrm{~S}$ rRNA } & 28S-Far & 9 & 5'-CACGAGACCGATAGCGAA CAAGTA-3' & McFadden and van Ofwegen 2013 & \multirow[t]{3}{*}{$50^{\circ} \mathrm{C} 90: 90: 60 \times 30$} \\
\hline & 28S-Rar & 10 & 5'-TCATTTCGACCC TAAGACCTC-3' & McFadden and van Ofwegen 2013 & \\
\hline & 28S-R3 & 11 & 5'-ACTGCATRTATGAACTCCA-3' & Present paper & \\
\hline
\end{tabular}

Table 2. - Gorgoniidae species involved in the molecular comparisons carried out in this study. Materials in bold are species sequenced for this study. Sequences with duplicate complete names are also numbered (e.g. 1-6) for the purpose of correctly identifying the sequence in Figure 8.

\begin{tabular}{|c|c|c|c|c|}
\hline Species & $\mathrm{Igr}+\mathrm{COI}$ & mtMutS & ITSs & $28 \mathrm{~S}$ \\
\hline Antillogorgia bipinnata & GQ342423 & GQ342499 & EU043125 & JX203712 \\
\hline Eugorgia ahorcadensis & KX721173 & KX721192 & KX721211 & KX721230 \\
\hline Eugorgia daniana (1) & KX721188 & KX721207 & KX721226 & KX721245 \\
\hline Eugorgia daniana (2) & KX721189 & KX721208 & KX721227 & KX721246 \\
\hline Leptogorgia alba (1) & KX721176 & KX721195 & KX721214 & KX721233 \\
\hline Leptogorgia alba (2) & KX721182 & KX721201 & KX721220 & KX721239 \\
\hline Leptogorgia alba (3) & KX721183 & KX721202 & KX721221 & KX721240 \\
\hline Leptogorgia alba (4) & KX721184 & KX721203 & KX721222 & KX721241 \\
\hline Leptogorgia alba (5) & KX721186 & KX721205 & KX721224 & KX721243 \\
\hline Leptogorgia alba (6) & KX721187 & KX721206 & KX721225 & KX721244 \\
\hline Leptogorgia manabiensis n. sp. (1) & KX721177 & KX721196 & KX721215 & KX721234 \\
\hline Leptogorgia manabiensis n. sp. (2) & KX721178 & KX721197 & KX721216 & KX721235 \\
\hline Leptogorgia manabiensis n. sp. (3) & KX721179 & KX721198 & KX721217 & KX721236 \\
\hline Leptogorgia manabiensis n. sp. (4) & KX721180 & KX721199 & KX721218 & KX721237 \\
\hline Leptogorgia manabiensis n. sp. (5) & KX721181 & KX721200 & KX721219 & KX721238 \\
\hline Leptogorgia manabiensis n. sp. (6) & KX721185 & KX721204 & KX721223 & KX721242 \\
\hline Leptogorgia diffusa & KX721190 & KX721209 & KX721228 & KX127247 \\
\hline Leptogorgia mariarosae & KX721174 & KX721193 & KX721212 & KX721231 \\
\hline Leptogorgia obscura & KX721191 & KX721210 & KX721229 & KX721248 \\
\hline Pacifigorgia stenobrochis & KX721175 & KX721194 & KX721213 & KX721232 \\
\hline
\end{tabular}

The model that best fit for nucleotide evolution for each final alignment was determined with jModelTest (Posada 2008). Phylogenetic analyses were performed using PhyML v3.0 for Maximum Likelihood (ML) (Guindon and Gascuel 2003). Maximum Parsimony (MP) was calculated in PAUP 4 b10 (Swofford 2003). MP parameters included a heuristic search with tree bisection-reconnection branch swapping.

ML and MP supports were determined through 1000 bootstrap replicates (bootstrap values $=b v$ ). Bayesian inference of phylogenetic relationships was performed in MrBayes 3.1 (Huelsenbeck and Ronquist 2001), employing two parallel runs of 5 million generations, verifying their convergence in Tracer v1.4 (Rambaut and Drummond 2007) and looking that standard deviations of split frequencies were smaller than 0.01 , with one cold and three heated Markov Chains Monte Carlo (MCMC) for each run, sampling one every 1000 replicates. The first $10 \%$ of sampled trees were discarded as burn-in, and support was evaluated based on posterior probabilities (pp).

\section{RESULTS}

Based on the evidence provided by the study of the differentiation of two Leptogorgia morphs, supported mainly by morphological and morphometric analyses, and framed by their evolutionary history, here we describe a new species within the family Gorgoniidae.

\section{Morphological characterization}

Family GorgoniIDAE Lamouroux, 1812 Genus Leptogorgia Milne-Edwards and Haime, 1857

\section{Leptogorgia manabiensis n. $\mathrm{sp}$.} (Figs 3-4)

Collected examined material: Holotype: MECN (Ant0001), Los Ahorcados, Manabí (Ecuador), 140'44"S 8050'08"W, 15 m depth, 27 Feb. 2010, six colonies.

Paratypes: MNCN (2.04/1190), Isla de Salanago, Manabí (Ecuador), $1^{\circ} 35^{\prime} 55.13^{\prime \prime S} 80^{\circ} 52^{\prime} 0.01^{\prime \prime} \mathrm{W}, 7 \mathrm{~m}$ depth, 20 Nov. 2011 , one colony. MZB (2017-0231), Punta Mala, Manabí (Ecuador), 1³5'55.13"S $80^{\circ} 52^{\prime} 0.01^{\prime \prime} \mathrm{W}, 10 \mathrm{~m}$ depth, 20 Nov. 2011, one colony. Other material: MNCN (2.04/1191), Los Frailes, Manabí (Ecuador), 1³0'14"S $80^{\circ} 48^{\prime} 33^{\prime \prime} \mathrm{W}, 10 \mathrm{~m}$ depth, $1 \mathrm{Feb} .2012$, one colony. MECN (Ant0026), Isla de la Plata, Manabí (Ecuador), $1^{\circ} 16^{\prime} 25.84^{\prime \prime} \mathrm{S} 81^{\circ} 4^{\prime} 11.70^{\prime \prime} \mathrm{W}, 15$ m depth, 22 Feb. 2012, two colonies. BEIM (OGORG-193), Isla de la Plata, Manabí (Ecuador), $1^{\circ} 16^{\prime} 25.84^{\prime \prime} \mathrm{S} 81^{\circ} 4^{\prime} 11.70^{\prime \prime} \mathrm{W}, 22 \mathrm{~m}$ depth, 22 Feb. 2012, one colony. MECN (Ant0018), Isla de Salango, Manabí (Ecuador), $1^{\circ} 35^{\prime} 55.13^{\prime \prime} \mathrm{S} 80^{\circ} 52^{\prime} 0.01^{\prime \prime} \mathrm{W}, 7 \mathrm{~m}$ depth, 20 Nov 2011, four colonies. MZB (2017-0232), Isla de Salango, Manabí (Ecuador), $1^{\circ} 35^{\prime} 55.13^{\prime \prime} \mathrm{S} 80^{\circ} 52^{\prime} 0.01^{\prime \prime} \mathrm{W}, 7 \mathrm{~m}$ depth, 20 Nov. 2011, one colony. MECN (Ant0002), Los Ahorcados, Manabí (Ecuador), $1^{\circ} 40^{\prime} 44^{\prime \prime} \mathrm{S} 80^{\circ} 50^{\prime} 08^{\prime \prime} \mathrm{W}, 5 \mathrm{~m}$ depth, $27 \mathrm{Feb}$. 2010, three colonies. MECN (Ant002), Los Ahorcados, Manabí (Ecuador), 1 ${ }^{\circ} 40^{\prime} 44^{\prime \prime} \mathrm{S}$ $80^{\circ} 50^{\prime} 08^{\prime \prime} \mathrm{W}, 10 \mathrm{~m}$ depth, $27 \mathrm{Feb}$. 2010, five whole colonies. 

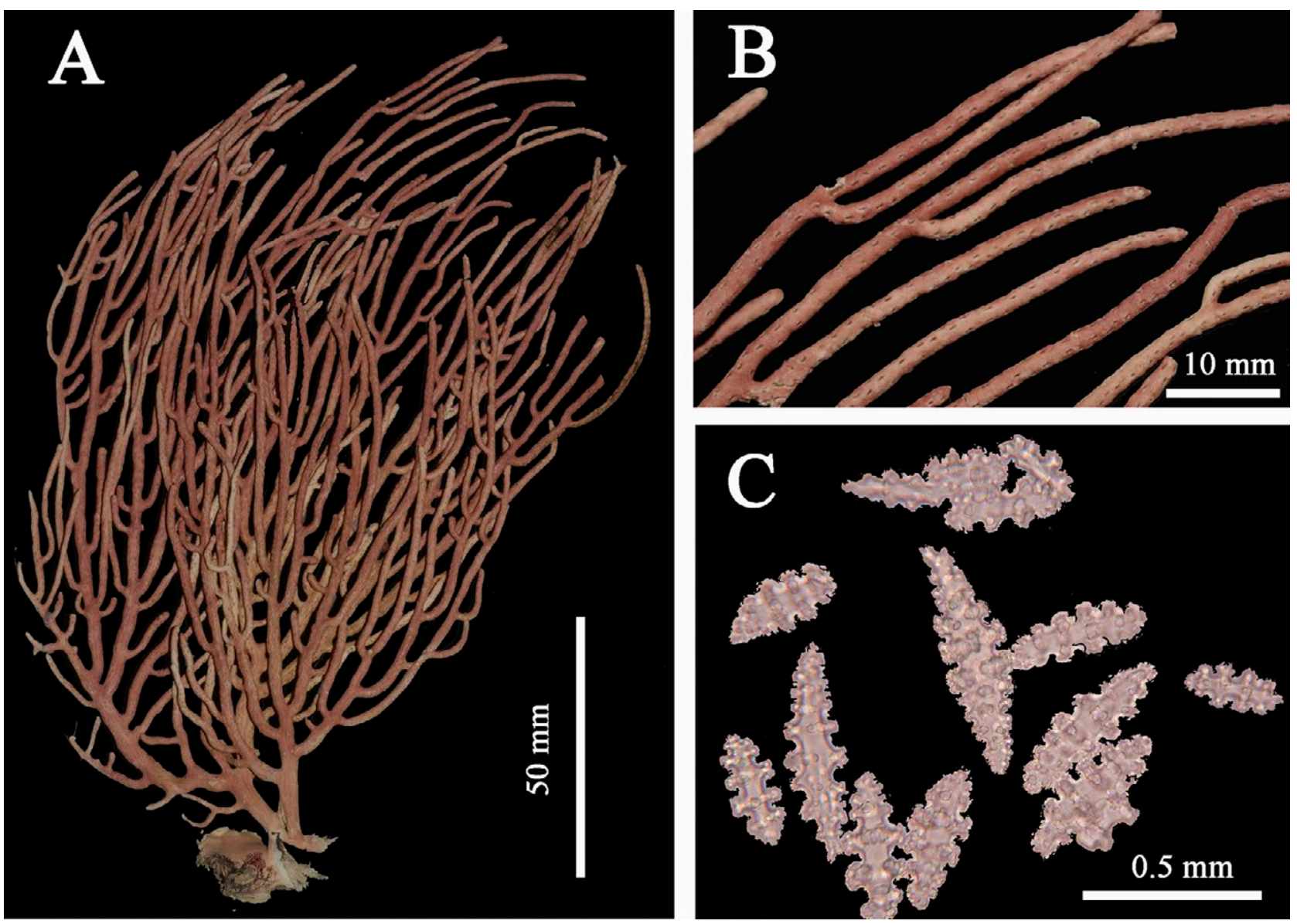

Fig. 3. - Leptogorgia manabiensis n. sp. (Ant0001), holotype. A, colony; B, detail of a branch; C, light micrograph of sclerites.

MECN (Ant0075), Los Ahorcados, Manabí (Ecuador), 140'44"S $80^{\circ} 50^{\prime} 08^{\prime \prime} \mathrm{W}, 20 \mathrm{~m}$ depth, $27 \mathrm{Feb}$. 2010, four colonies. MECN (Ant0031), Los Frailes, Manabí (Ecuador), 1³0'14"S 8048'33"W, $15 \mathrm{~m}$ depth, 1 March 2012, one colony. MECN (Ant0073), Punta

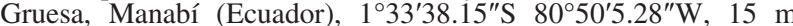
depth, 12 Sept. 2012, one colony. MECN (Ant0076), Punta Gruesa, Manabí (Ecuador), $1^{\circ} 33^{\prime} 38.15^{\prime \prime} \mathrm{S} 80^{\circ} 50^{\prime} 5.28^{\prime \prime} \mathrm{W}, 14 \mathrm{~m}$ depth, 3 Feb. 2013, four colonies. MECN (Ant0017), Punta Mala, Manabí (Ecuador), $1^{\circ} 33^{\prime} 41.37^{\prime \prime S} 80^{\circ} 50^{\prime} 8.79^{\prime \prime} \mathrm{W}, 15 \mathrm{~m}$ depth, 20 Nov. 2011, two colonies. MECN (Ant0074), Punta Mala, Manabí (Ecuador), $1^{\circ} 33^{\prime} 41.37^{\prime \prime} \mathrm{S} 80^{\circ} 50^{\prime} 8.79^{\prime \prime} \mathrm{W}, 16 \mathrm{~m}$ depth, 3 Feb. 2013, five colonies.

Description of the holotype. The colony is 155 $\mathrm{mm}$ long and $120 \mathrm{~mm}$ wide, irregularly pinnate; branches slender, mostly in a plane (Fig. 3A). Living colony dark pink in colour, and pink or light pink in a dried state. Unbranched distal twigs up to 50 $\mathrm{mm}$ in length and $19 \mathrm{~mm}$ in diameter, compressed proximally, more cylindrical and slightly tapered distally (Fig. 3A, B). Slightly marked longitudinal grooves along the thick basal branches and near the base. Polyps retract within slightly raised polyp mounds, sparsely distributed all around the branches with oblong apertures (Fig. 3B). Coenenchymal sclerites colourless (Fig. 3C). Dominant sclerite type spindles, straight or bent, some with a marked waist, measuring up to $0.14 \mathrm{~mm}$ in length and $0.04 \mathrm{~mm}$ width with 4-6 whorls of tubercles (Figs 3C, 4A). Capstans measure up to $0.08 \mathrm{~mm}$ in length and 0.03 mm wide (Fig. 3B). Crosses not present. Anthocodial sclerites hyaline or colourless, rods measure up

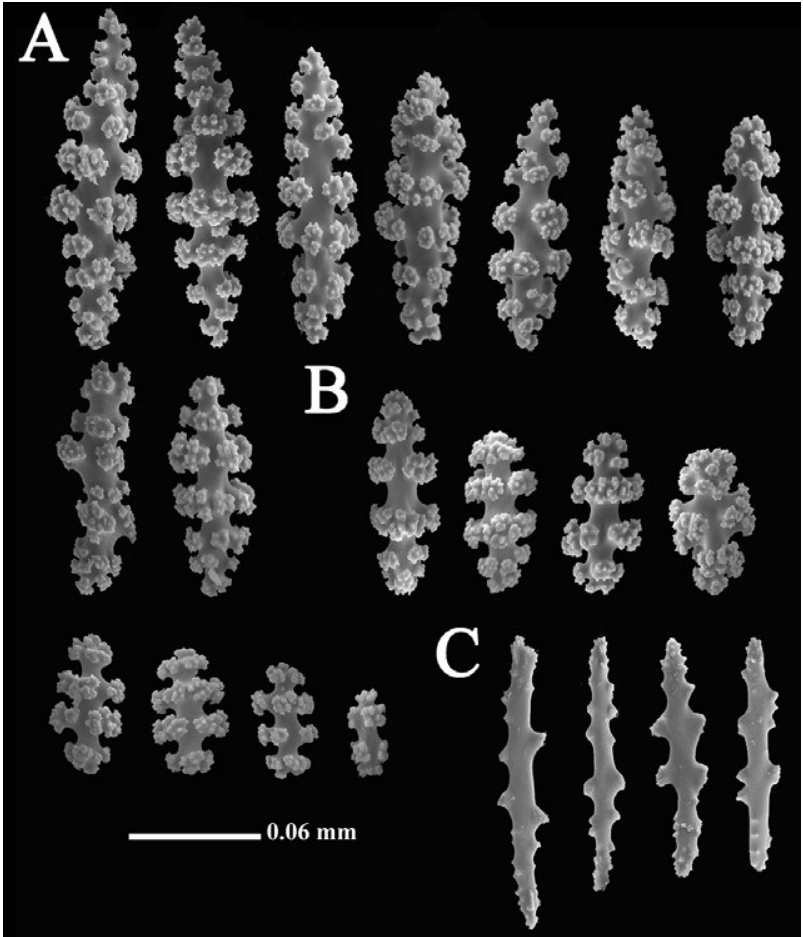

Fig. 4. - Leptogorgia manabiensis n. sp. (Ant0001), holotype SEM photographs. Coenenchymal sclerites, A, spindles; B, captans; anthocodial sclerites, $\mathrm{C}$, rods. 
to $0.10 \mathrm{~mm}$ in length and $0.02 \mathrm{~mm}$ wide, with some marginal projections (Figs 3C, 4C).

Variability. Colonies vary up to a maximum of 316 $\mathrm{mm}$ in length and $236 \mathrm{~mm}$ in width. Unbranched distal twigs measure up to $13.9 \mathrm{~cm}$ in length and $19 \mathrm{~mm}$ in diameter. Spindles measure 0.06-0.17 $\mathrm{mm}$ in length and 0.03-0.06 $\mathrm{mm}$ in width. Capstans measure 0.03-0.10 $\mathrm{mm}$ in length and $0.02-0.07 \mathrm{~mm}$ in width. Anthocodial sclerite rods measure $0.05-0.14 \mathrm{~mm}$ in length and 0.01 $0.06 \mathrm{~mm}$ in width.

Geographic and bathymetric distribution. Leptogorgia manabiensis $\mathrm{n}$. sp. is known from the type locality in Los Ahorcados, Cope, Los Frailes, Punta Gruesa, Punta Mala, Isla de Salango and Isla de la Plata (continental coast of Ecuador), living on rocky bottoms in shallow waters at a depth of 5-23 m.

Etymology. The specific epithet refers to the Province of Manabí (Ecuador), the type locality where the new taxon was discovered.

Remarks. According to classical morphological characters, L. alba and L. manabiensis n. sp. show two main differences (Figs 3, 4, 5, 6). The first is colony colour, which is clearly distinct between the two spe- cies (Fig. 1): L. alba is white (alive and dry) and $L$. manabiensis n. sp. is deep pink (alive) and pink/light pink (dry). The second difference is the length and diameter of the unbranched distal branches, which are slightly longer and thicker in $L$. alba, up to $153 \mathrm{~mm}$ in length and $2.7 \mathrm{~mm}$ in diameter. In L. manabiensis n. sp., unbranched distal twigs reach up to $139 \mathrm{~mm}$ in length and $1.9 \mathrm{~mm}$ in diameter. Other differences found between the two studied species are discussed in the morphometric analysis section below.

For a complete description and list of the materials of Leptogorgia alba examined for this study, see SolerHurtado et al. (2016).

\section{Morphometric analyses}

Nine morphological characteristics were selected: maximum height, maximum length of the primary branches to maximum height ratio, order of colony, bifurcation ratio, tributary to source ratio of secondary order branches, main thickness of the primary order branches, angle formed between primary and secondary order branches, angle formed between secondary and tertiary order branches, and angle formed by basal branches. There were significant differences in the multivariate structure between the species, L. alba and L. manabiensis n. sp.,

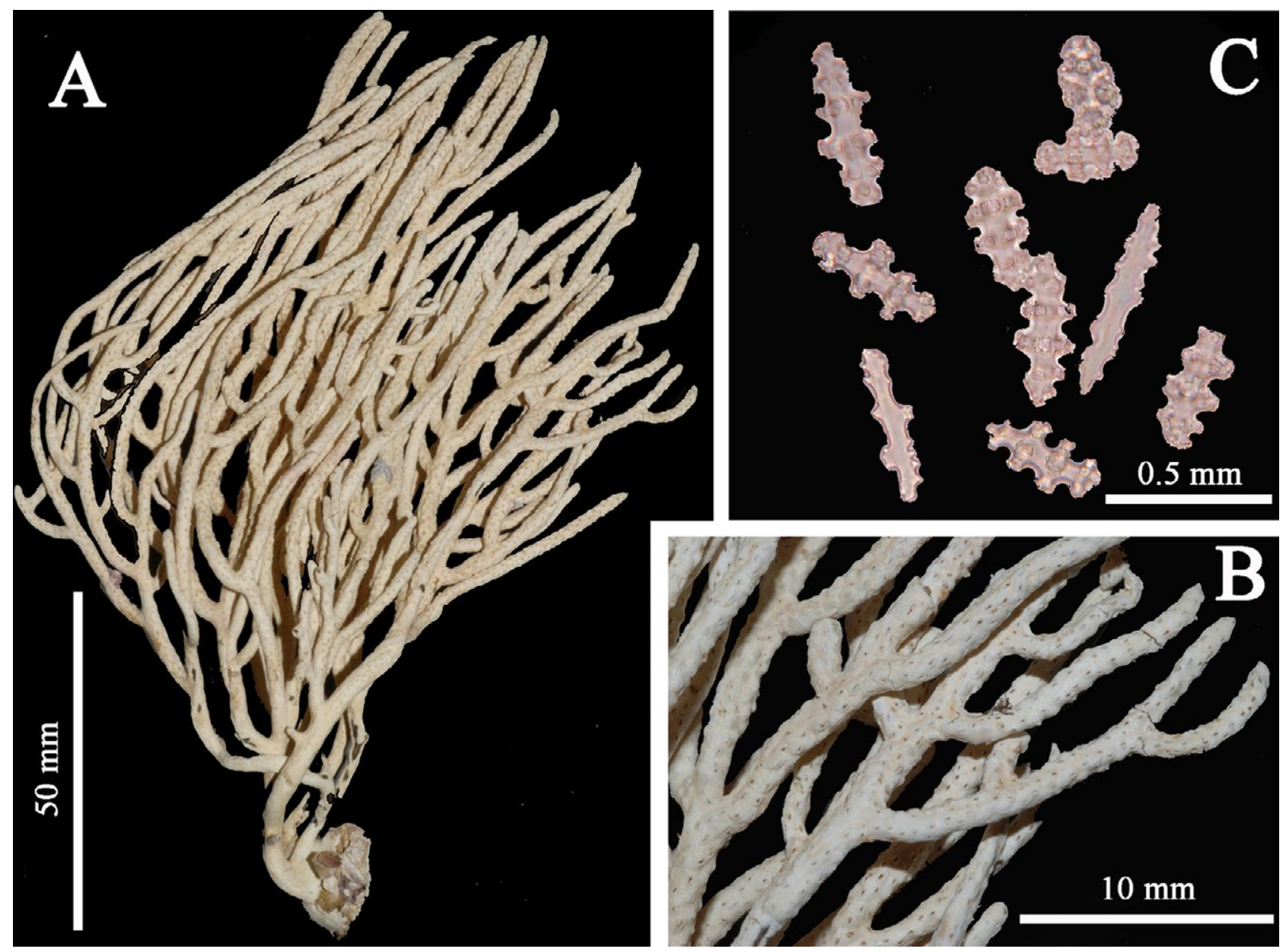

Fig. 5. - Leptogorgia alba (BEIM-0071). A, colony; B, detail of a branch; C, light micrograph of sclerites. 
Table 3. - PERMANOVA table of results. Two crossed fixed factors: morph and size.

\begin{tabular}{lccccc}
\hline & df & SS & MS & Pseudo-F & P(perm) \\
\hline Morph & 1 & 39.80 & 39.80 & 5.67 & $<0.01$ \\
Size & 3 & 129.5 & 43.16 & 6.15 & $<0.01$ \\
Morph $\times$ size & 3 & 29.79 & 9.93 & 1.41 & 0.10 \\
Residual & 69 & 484.22 & 7.01 & & \\
Total & 76 & 684 & & & \\
\hline
\end{tabular}

and among colony size class (Table 3). Interactions between species and size class were not detected. The multivariate dispersion did not show any significant difference, either between the levels of the factor "morph" (PERMDISP F1,75: 2.25; P(perm): 0.14 ), or among the levels of the factor "size" (PERMDISP F1,73: 1.22; P(perm): 0.36). Figure 7 shows a graphical comparison of the nine morphological characteristics analysed in the two gorgonian species. Colonies of L. alba tended to be characterized by higher maximum length of the primary branches to maximum height ratio, the angle formed between primary and secondary order branches, the angle formed between secondary and tertiary order branches, and the angle formed by basal branches (Fig. 7). In contrast, colonies of L. manabiensis n. sp. tended to be characterized by a higher order of colony, bifurcation ratio, and tributary to source ratio of secondary order branches (Fig. 7). In summary, the two forms cannot be considered as ontogenetic stages of a single species.

\section{Molecular analyses}

One matrix was prepared with the concatenated data from the four marker alignments: mtMutS+Cox+ITSs+28S (16 specimens, 3353 characters). New sequences were deposited in GenBank (Table 2). According to jModelTest, the nucleotide substitution model that best fit the data was HKY+I. Trees obtained by Bayesian, MP and ML analyses all showed the same topology. In the concatenated alignment including the outgroups, a total of 152 sites were parsimony-informative. However, only 7 sites were parsimony-informative between $L$. manabiensis $\mathrm{n}$. sp. and L. alba: six from the ITSs region and one from $28 \mathrm{~S}$. The mitochondrial fragments were uninformative. Thus, the topology of the concatenated tree largely matched the tree obtained using nuclear data alone (ITSs+28S) (not shown).

The reconstruction based on the data obtained from the four concatenated genes (Fig. 8) showed a well-supported Leptogorgia alba-L. manabiensis n. sp. clade (Clade I) $(\mathrm{pp}=1 ; \mathrm{bv}=100)$. Specimens of $L$. alba and L. manabiensis n. sp. were divided into different subclades, but without taxonomic congruence. A well-supported polyphyletic assemblage consisting of Eugorgia daniana as sister group to the $L$. alba $+L$. manabiensis n. sp. clade and E. ahorcadensis (Clade II) was also observed $(\mathrm{pp}=1 ; \mathrm{bv} \geq 85)$. Leptogorgia diffusa and $L$. obscura, which are closely related to $L$. mariarosae (Clade III), formed the sister group to Clade II $(\mathrm{pp} 0=1 ;$ bv $\geq 97)$. Pacifigorgia stenobrochis and Antilogorgia bipinnata (designated as an outgroup) were basal to clades I, II and III.

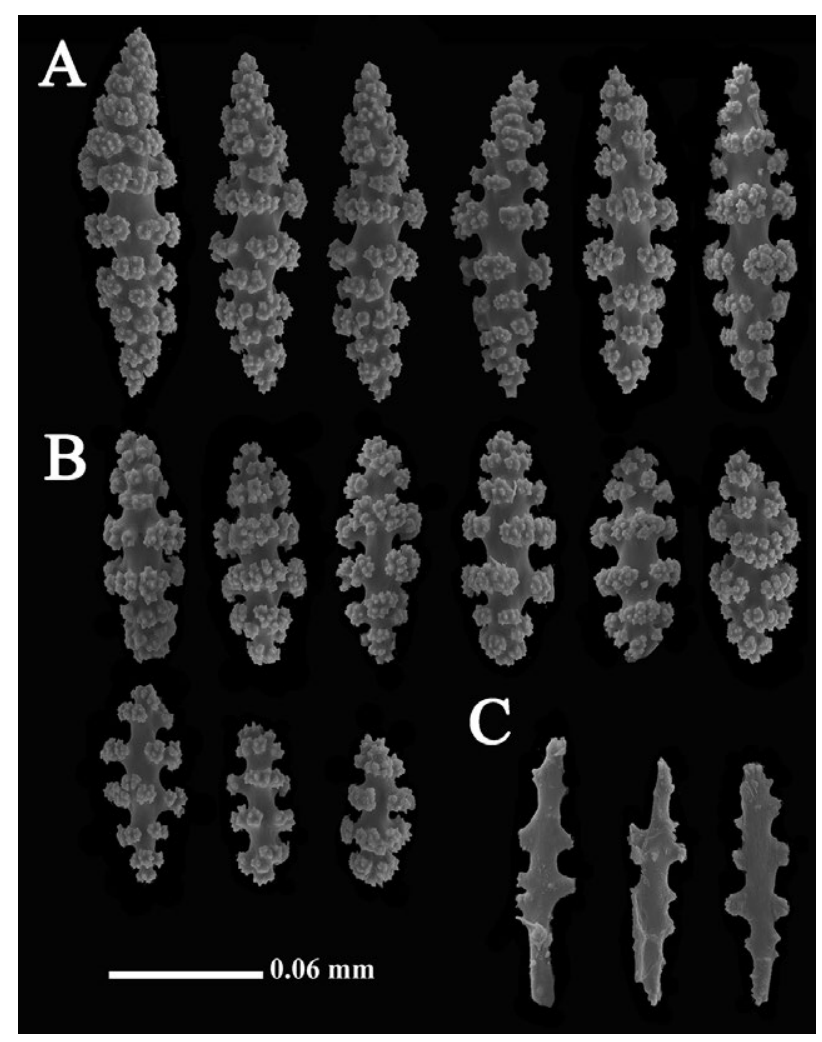

Fig. 6. - Leptogorgia alba (BEIM-0071) SEM photographs. Coenenchymal sclerites: A, spindles; B, captans; Anthocodial sclerites: $\mathrm{C}$, rods

\section{DISCUSSION}

The morphological and morphometric results presented here, which showed significant differences in colony shape and branching, support the existence of two distinct species, L. alba and L. manabiensis n. sp., coexisting in Machalilla National Park (Ecuador). In addition, the molecular data has contributed to our understanding of the evolutionary history of this group of species. Overall, we have shown that the delimitation and identification of challenging species is possible through an integrative taxonomic approach based on morphology and on molecular and morphometric techniques. Indeed, in this study, evidence based on morphological, molecular and morphometric analyses have provided three semi-independent datasets. Taken together, these evidences help to better understand the true diversity and evolutionary history within this species group.

Previous morphological studies based on a limited set of characters, including L. alba (Breedy and Guzman 2007), suggested that variability in colony colour and shape represented intraspecific morphological variation, correlated with differences in environmental factors principally due to local currents and depth (Lewis and Wallis 1991, Carlon and Budd 2002, Gori et al. 2012). However, the two species analysed here were living in close proximity in the same study area; thus, differences in colony morphology between $L$. alba and L. manabiensis n. sp. cannot be attributed to phenotypic plasticity based on environmental conditions or ecological niches. 

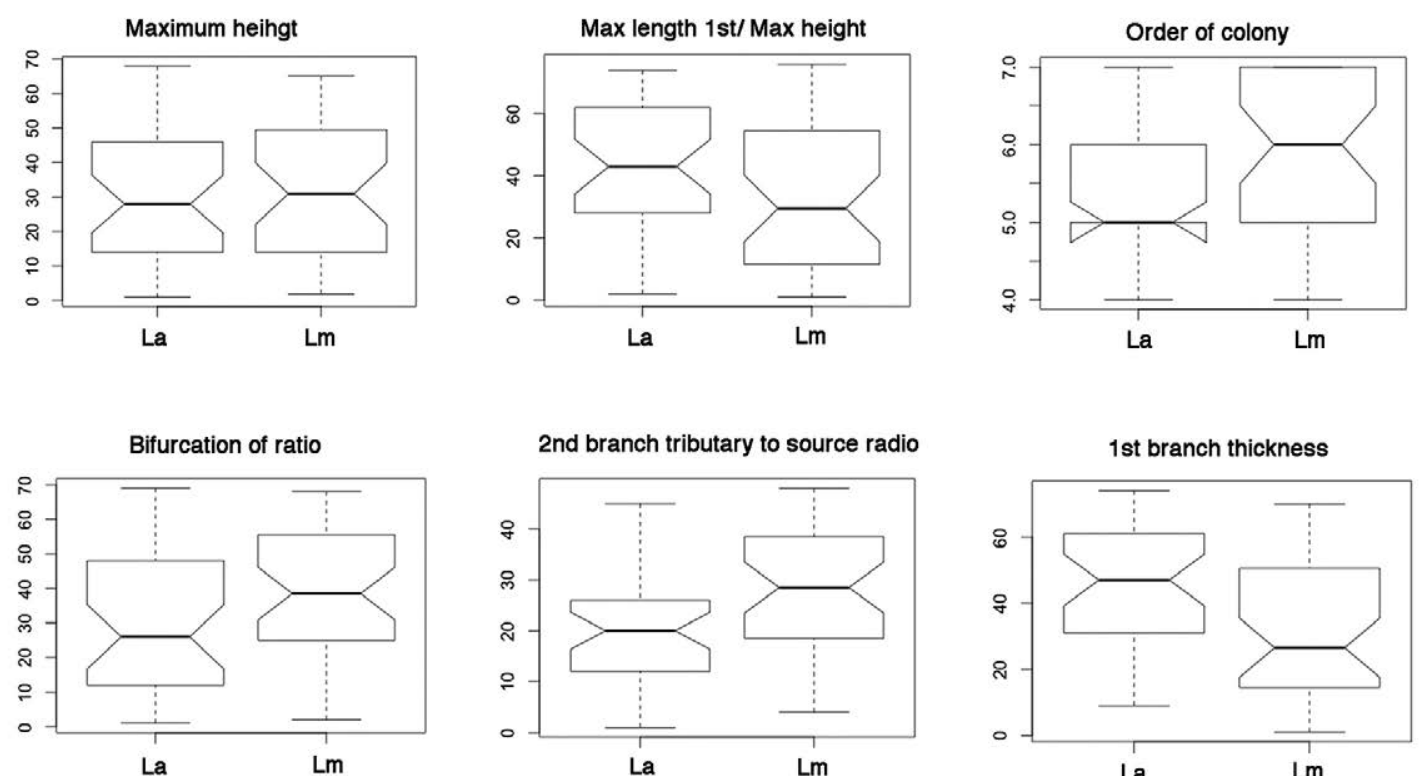

2nd branch tributary to source radio

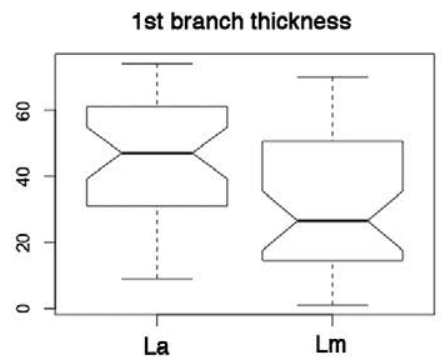

1st - 2nd branch angle
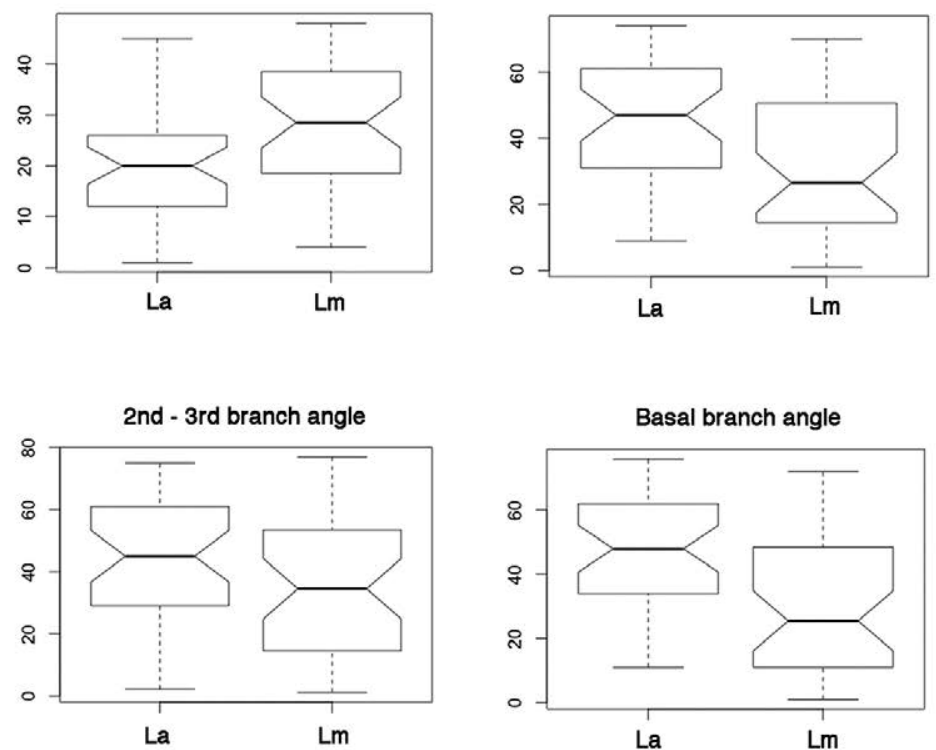

Lm

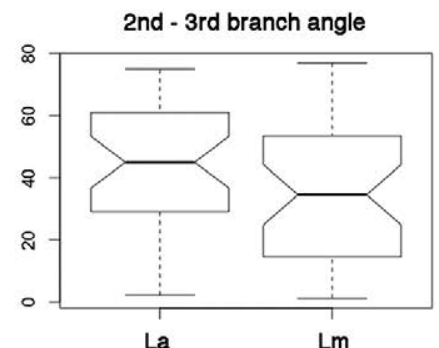

Fig. 7. - Graphical representation of selected morphometric colony features for L. alba (La) and for L. manabiensis $\mathrm{n}$. sp. (Lm) (n=80). Thick black lines indicate mean values, and dotted vertical lines indicate the dispersion range values.

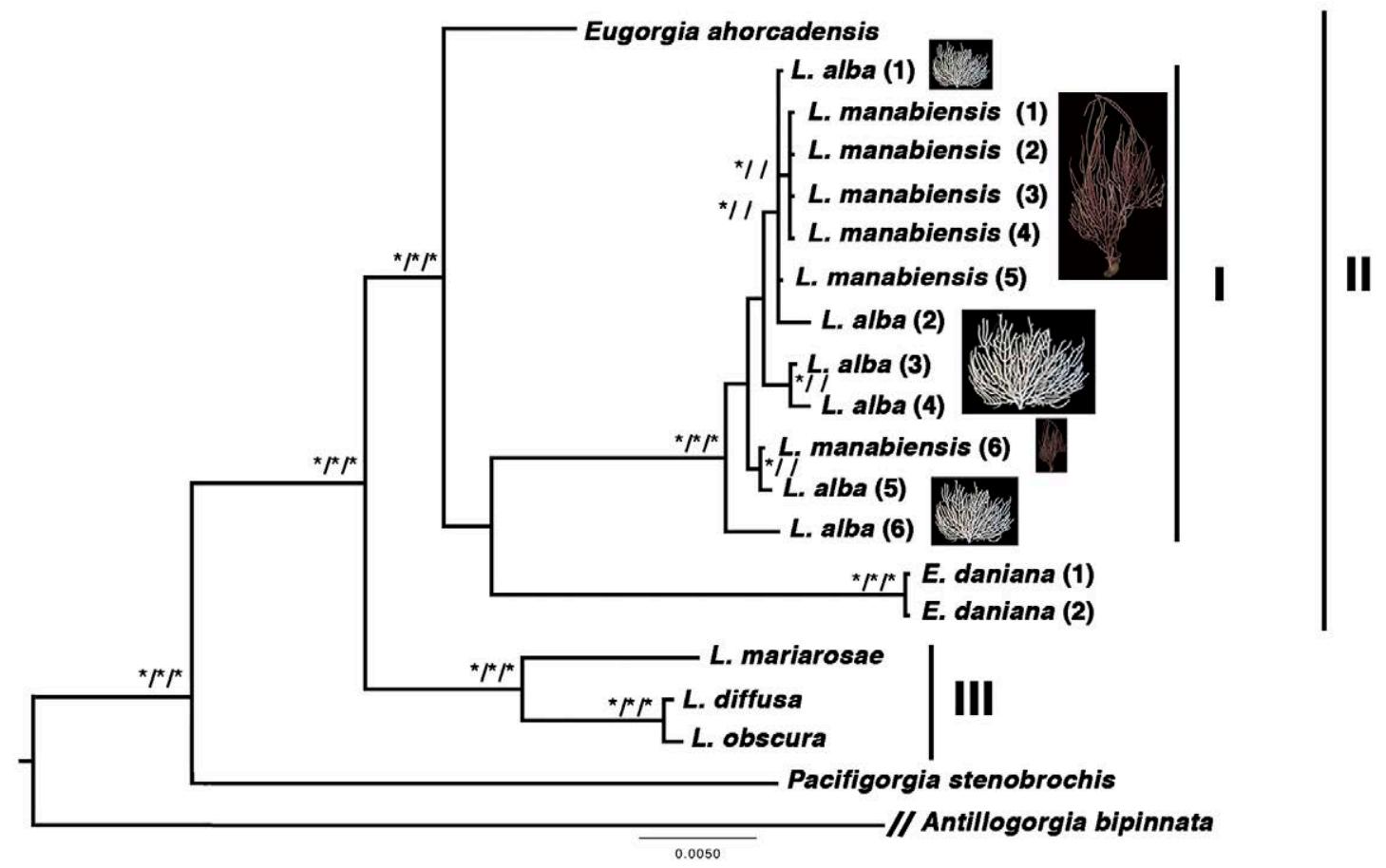

Fig. 8. - Phylogenetic relationships between 20 specimens from the Gorgoniidae family ( 7 species, 4 genera). Tree topology was inferred by Bayesian analysis, based on combined mitochondrial (coxII+Igr+coxI and mtMutS) and nuclear (ITSs and 28S) genes. The stars indicate clade supports for BI/ML/MP ( $\mathrm{pp} \geq 95$; bootstrap=70). Sequences with duplicate, complete names were also numbered (e.g. 1, 2, 3, etc.) for the purpose of correctly identifying the sequence in the phylogenetic tree. 
Moreover, Guzman and Breedy (2008) divided the genus Leptogorgia into three species groups based on morphological characteristics, including an "alba-group" consisting of some species "with flat or slightly raised polyp-mounds, pinnate or dichotomous branching and white colonies" (Guzman and Breedy 2008). In addition, Ament-Velásquez et al. (2016), using molecular phylogenetic analyses, demonstrated that the white phenotype was consistent and revealed a synapomorphy for the previously defined "albagroup". In light of our analyses, based on the morphological definition of the "alba-group", L. manabiensis n. sp. must not be considered part of it due to its pink colour, reinforcing the idea that it is a differentiated species. However, on the other hand, the molecular similarity and relationship between L. manabiensis n. sp. and $L$. alba revealed the artificialness of using colour as a character to define this "alba-group".

Most of the morphometric characters considered in this study were not noted in previous descriptions and revisions. In addition, our study shows that the differences between L. alba and L. manabiensis $\mathrm{n}$. sp. were significant in all size classes, so not restricted to only larger individuals or specimens in the first stage of development. In a speciation framework, some morphological characteristics might remain stable for each species (e.g. the colour of the colony, some morphometric branching measures), while others are shared between the two species (Forsman et al. 2010, Vollmer and Palumbi 2004). Given the importance of understanding the morphological variation present in these organisms, the mechanisms and heritability involved in this variation should be considered (Vermeij et al. 2007). Indeed, these variations could be due to genetic polymorphisms, in which the morphology of the species is determined by genotypes, independent of the ecological niche occupied (Carlon and Budd 2002, Vermeij et al. 2007).

The significant differences observed in the morphometric and morphological analyses were not completely consistent with our molecular results, in which the relationship between $L$. alba and L. manabiensis $\mathrm{n}$. sp. resulted in a polyphyletic assemblage. As expected, the mitochondrial data were only useful for comparing the ingroup (L. alba and L. manabiensis $\mathrm{n}$. sp.) and outgroup, confirming the need to complement the use of these markers with nuclear ones in the study of close relationships (Yasuda et al. 2015, Aguilar and Sánchez 2007, McFadden et al 2010). Hybridization or incomplete lineage sorting, in which L. alba and L. manabiensis n. sp. unequally share a genetic polymorphism, may also explain the lack of congruence of the molecular nuclear data. This phenomenon has been observed between closely related species within other coral genera such as Heliopora (Yasuda et al. 2015), Seriatopora (Flot et al. 2008) and Acropora (Vollmer and Palumbi 2004), and in other invertebrates such as Cypraeidae marine gastropods (Meyer and Paulay 2005), Melanoplus grasshopper species (Carstens and Knowles 2007) and the butterfly family Lycaenidae (Wiemers and Fiedler 2007).
Although for some molecular phylogenies of corals, hybridization processes have been used to explain a lack of resolution, polyphyly or paraphyly (Hatta et al. 1999, Diekmann et al. 2001, McFadden and Hutchinson 2004), possible ancestral polymorphisms linked to a delayed process of evolution, such as a source of shared haplotypes between species, should also be considered (van Oppen et al. 2001, Vollmer and Palumbi 2004). Incomplete lineage sorting can be a particularly important factor to consider for rapidly and recently diverged species (Hoelzer and Melnick 1994, Henning and Meyer 2014, Eberle et al. 2016), as it makes species misidentifications more likely, thus leading to conflicting or misleading findings (van Velzen et al. 2012, Nater et al. 2015). Although the molecular analyses were unable to provide diagnostic characters for the complete delimitation of L. alba and L. manabiensis n. sp., they indicated that the phenotypic variation observed may be the result of a recent speciation and diversification event.

Wirshing and Baker (2015) suggested that, due to the common limited genetic variation within gorgonian species, a re-evaluation of species-level morphological characters is needed. Followed this recommendation, we provide new diagnostic morphometric characters (e.g., bifurcation ratio, branch thickness and branch angle) to complement classical morphological characters used for species identification, within an evolutionary context.

Evolutionary status and the relatedness of species, and the traits used to identify them, may not have a direct positive relationship (Carlon and Budd 2002). However, this is not to say that diagnostic species criteria are not mutually exclusive: alternate criteria could indicate different aspects of biological information, providing more robust support about the identification of species boundaries (Rocha-Olivares et al. 2001).

Overall, the differentiation reported here between the new species $L$. manabiensis n. sp. and L. alba may help clarify previously cited discrepancies and reduce unexplained variability in these challenging gorgonian species. Moreover, this study confirms that the use of other tools and frameworks can be valuable for delimiting species for comparative studies.

Of the approximately 28 Leptogorgia species that have been described for the eastern Pacific (Breedy and Guzman 2007; Horvath 2011), six (including $L$. manabiensis n. sp.) are distributed along the relatively unknown coasts of Ecuador (Soler-Hurtado and LópezGonzález 2012, Soler-Hurtado et al. 2016, this paper). Many of the species descriptions of Leptogorgia in the eastern Pacific have come from specimens collected from northern localities such as California, Mexico, Costa Rica, and Panama (Breedy and Guzman 2005, 2007, Breedy et al. 2012). Therefore, this study increases our knowledge of the biodiversity of this group for other regions of this ocean. Furthermore, it reinforces the observation that Leptogorgia diversity is higher along the eastern Pacific coast of the Americas than along the western Atlantic coast, where only 12 valid recognized species are known to date (Bayer 1961, Devictor and Morton 2010). To better understand the evolution and biodiversity of gorgonian gardens, and 
to implement effective conservation strategies, future research focusing on the biological, ecological, and behavioural characters of these organisms are necessary, especially in the case of L. manabiensis n. sp., due to its restricted distribution area.

\section{ACKNOWLEDGEMENTS}

This research was partially supported by a grant from the Spanish Ministry of Economy and Competitiveness (CTM2014-57949-R). Our appreciation goes to Santiago Villamarín (Museo Ecuatoriano de Ciencias Naturales), Machalilla National Park and the Ministerio del Ambiente of Ecuador (Manabí) for participation and collection permits ( $\mathrm{N}^{\mathrm{o}}$ 016-RM-DPM-MA). We thank Michel Guerrero and his team (Exploramar Diving) for his special interest and collaboration. Melinda Modrell carefully reviewed the language. Special thanks to Micaela Peña for her strong support.

\section{REFERENCES}

Abràmoff M.D., Magalhães P.J., Ram S.J. 2004. Image processing with imageJ. Biophotonics. Int. 11: 36-41.

Aguilar C., Sánchez J.A. 2007. Molecular morphometrics: Contribution of ITS2 sequences and predicted RNA secondary structures to octocoral systematics. Bull. Mar. Sci. 81: 335-349.

Alderslade P. 1998. Revisionary systematics in the gorgonian family Isididae: with descriptions of numerous new taxa (Coelenterata: Octocorallia). Rec. West. Aust. Museum. 55: 1-359.

Alfaya J.E.F., Bigatti G., Kajihara H., et al. 2015. DNA barcoding supports identification of Malacobdella species (Nemertea: Hoplonemertea). Zool. Stud. 54: 10. https://doi.org/10.1186/s40555-014-0086-3

Ament-Velásquez S.L., Breedy O., Cortés J., et al. 2016. Homoplasious colony morphology and mito-nuclear phylogenetic discordance among Eastern Pacific octocorals. Molec. Phylogenet. Evol. 98: 373-381. https://doi.org/10.1016/j.ympev.2016.02.023

Anderson M.J. 2001. A new method for non-parametric multivariate analysis of variance. Austral. Ecol. 26: 32-46. https://doi.org/10.1111/j.1442-9993.2001.01070.pp.x

Anderson M.J. 2006. Distance-based tests for homogeneity of multivariate dispersions. Biometrics 62: 245-253. https://doi.org/10.1111/j.1541-0420.2005.00440.x

Anderson M.J., Gorley R.N., Clarke K.R. 2008. PERMANOVA+ for PRIMER: Guide to Software and Statistical Methods. PRIMER-E, Plymouth, UK.

Bayer F.M. 1961. The shallow-water Octocorallia of the West Indian region. A manual for marine biologists. Stud. Fauna. Curacao. Caribb. Islands. 12: 1-373.

Bayer F.M. 2000. A new species of Leptogorgia from the eastern Pacific (Coelenterata: Octocorallia: Holaxonia). Proc. Biol. Soc. Washingt. 113: 609-616.

Bayer F.M., Stefani J. 1989. Primnoidae de Nouvelle-Calédonie. Bull. Mus. Nat. His. Nat. Paris. 4 ser., Sect A. 3: 449-476.

Bayer F.M., Grasshoff M., Verseveldt J. 1983. Illustrated trilingual glossary of morphological terms applied to Octocorallia. Brill E.J. (ed), Leiden.

Bielschowsky E. 1929. Die Gorgonarien Westindien. 6. Die Familie Gorgoniidae, zugleich eine Revision. Zool. Jahrbücher. Suppl. 16: 63-234.

Brazeau D.A., Lasker H.R. 1988. Inter- and intraspecific variation in gorgonian colony morphology: quantifying branching patterns in arborescent animals. Coral Reefs 7: 139-143. https://doi.org/10.1007/BF00300973

Breedy O., Guzman H.M. 2003. Octocorals from Costa Rica: The genus Pacifigorgia (Coelenterata: Octocorallia: Gorgoniidae). Zootaxa 281: 1-60. https://doi.org/10.11646/zootaxa.281.1.1

Breedy O., Guzman H.M. 2005. A new species of Leptogorgia (Coelenterata: Octocorallia: Gorgoniidae) from the shallow waters of the eastern Pacific. Zootaxa 899: 1-11. https://doi.org/10.11646/zootaxa.899.1.1
Breedy O., Guzman H.M. 2007. A revision of the genus Leptogorgia Milne-Edwards and Haime, 1857 (Coelenterata: Octocorallia: Gorgoniidae) in the Eastern Pacific. Zootaxa 1419: 1-90. https://doi.org/10.11646/zootaxa.1419.1.1

Breedy O., Abeytia R., Guzman H.M. 2012. A new species of Leptogorgia (Cnidaria: Anthozoa: Octocorallia) from the Mexican Pacific coast. Bull. Mar. Sci. 88: 319-325. https://doi.org/10.5343/bms.2011.1103

Calvo M., Templado J., Oliverio M., et al. 2009. Hidden Mediterranean biodiversity: Molecular evidence for a cryptic species complex within the reef building vermetid gastropod Dendropoma petraeum (Mollusca: Caenogastropoda). Biol. J. Linn. Soc. 96: 898-912. https://doi.org/10.1111/j.1095-8312.2008.01167.x

Carlon D.B., Budd F.A. 2002. Incipient speciation across a depth gradient in a scleractinian coral? Evolution 56: 2227-2242. https://doi.org/10.1111/j.0014-3820.2002.tb00147.x

Carstens B.C., Knowles L.L. 2007. Estimating species phylogeny from gene-tree probabilities despite incomplete lineage sorting: an example from Melanoplus grasshoppers. Syst. Biol. 56: 400-411. https://doi.org/10.1080/10635150701405560

Clarke K.R., Gorley R.N. 2006. PRIMER v6: User manual/tutorial. PRIMER-E. $192 \mathrm{pp}$

Costantini F., Gori A., Lopez-González P., et al. 2016. Limited genetic connectivity between gorgonian morphotypes along a depth gradient. PLoS One 11: e0160678. https://doi.org/10.1371/journal.pone.0160678

Dayrat B. 2005. Towards integrative taxonomy. Biol. J. Linn. Soc. 85: 407-415. https://doi.org/10.1111/j.1095-8312.2005.00503.x

Devictor S.T., Morton S.L. 2010. Identification guide to the shallow water $(0-200 \mathrm{~m})$ octocorals of the South Atlantic Bight. Zootaxa 62: $1-62$.

Diekmann O.E., Bak R.P.M., Stam W.T., et al. 2001. Molecular genetic evidence for probable reticulate speciation in the coral genus Madracis from a Caribbean fringing reef slope. Mar. Biol. 139: 221-233 https://doi.org/10.1007/s002270100584

Dincă V., Lukhtanov V.A., Talavera G., et al. 2011. Unexpected layers of cryptic diversity in wood white Leptidea butterflies. Nat. Commun. 2: 324 https://doi.org/10.1038/ncomms1329

Duchassaing P., Michelotti J. 1864. Supplément au Mémoire sur les coralliaires des Antilles. Extr. Mém. Acad. Sci. Turin 2: 1-112.

Eberle J., Warnock R.C.M., Ahrens D. 2016. Bayesian species delimitation in Pleophylla chafers (Coleoptera) - the importance of prior choice and morphology. BMC. Evol. Biol. 16: 94. https://doi.org/10.1186/s12862-016-0659-3

Flot J.F., Licuanan W.Y., Nakano Y., et al. 2008. Mitochondrial sequences of Seriatopora corals show little agreement with morphology and reveal the duplication of a tRNA gene near the control region. Coral Reefs 27: 789-794. https://doi.org/10.1007/s00338-008-0407-2

Forsman Z., Conception G., Haverkort R. 2010. Is Montipora dilatata an endangered coral species or an ecotype? Genes and skeletal microstructure lump seven Hawaiian species into four groups. NOAA Rep: 20.

France S.C., Hoover L.L. 2002. DNA sequences of the mitochondrial COI gene have low levels of divergence among deep-sea octocorals (Cnidaria: Anthozoa). Hydrobiologia 471: 149-155. https://doi.org/10.1023/A: 1016517724749

Gori A., Bramanti L., López-González P.J., et al. 2012. Characterization of the zooxanthellate and azooxanthellate morphotypes of the Mediterranean gorgonian Eunicella singularis. Mar. Biol. 159: $1485-1496$ https://doi.org/10.1007/s00227-012-1928-3

Grasshoff M. 1988. The genus Leptogorgia (Octocorallia: Gorgoniidae) in West Africa. Atl. Rep. 14: 91-147.

Guindon S., Gascuel O. 2003. A simple, fast, and accurate algorithm to estimate large phylogenies by maximum likelihood. Syst. Biol. 52: 696-704. https://doi.org/10.1080/10635150390235520

Guzman H.M., Breedy O. 2008. Leptogorgia christiae (Octocorallia: Gorgoniidae) a new shallow gorgonian from Pacific Panama. Mar. Biol. Assoc. U.K. 88: 719-722. https://doi.org/10.1017/s0025315408001240

Hatta M., Fukami H., Wang W., et al. 1999. Reproductive and genetic evidence for a reticulate evolutionary history of massspawning corals. Mol. Biol. Evol. 16: 1607-1613. 
https://doi.org/10.1093/oxfordjournals.molbev.a026073

Hellberg M.E. 2006. No variation and low synonymous substitution rates in coral mtDNA despite high nuclear variation. BMC Evol. Biol. 6: 24. https://doi.org/10.1186/1471-2148-6-24

Henning F., Meyer A. 2014. The evolutionary genomics of cichlid fishes: explosive speciation and adaptation in the postgenomic era. Annu. Rev. Genomics. Hum. Genet. 15: 417-441. https://doi.org/10.1146/annurev-genom-090413-025412

Hoelzer G., Melnick D.J. 1994. Patterns of speciation and limits to phylogenetic resolution. Trends. Ecol. Evol. 9: 104-107. https://doi.org/10.1016/0169-5347(94)90207-0

Horton R.E. 1945. Erosional development of streams and their drainage basins; Hydrophysical approach to quantitative morphology. Bull. Geol. Soc. Am. 56: 275-370.

https://doi.org/10.1130/0016-7606(1945)56[275: EDOSAT]2.0.CO;2

Horvath E.A. 2011. An unusual new "sea fan" from the northeastern Pacific Ocean (Cnidaria: Octocorallia: Gorgoniidae). Proc. Biol. Soc. Washingt. 124: 45-52. https://doi.org/10.2988/10-27.1

Huelsenbeck J.P., Ronquist F. 2001. MRBAYES: Bayesian inference of phylogenetic trees. Bioinformatics 17: 754-755. https://doi.org/10.1093/bioinformatics/17.8.754

Hugall A, Stanton J, Moritz C. 1999. Reticulate evolution and the origins of ribosomal internal transcribed spacer diversity in apomictic Meloidogyne. Mol. Biol. Evol. 16: 157-164. https://doi.org/10.1093/oxfordjournals.molbev.a026098

Lewis J.C., Wallis E.V. 1991. The function of surface sclerites in gorgonians (Coelenterata, Octocorallia). Biol. Bull. 181: 275-288. https://doi.org/10.2307/1542099

López-González P.J., Grinyó J., Gili J.M. 2015. Chironephthya mediterranea n. sp. (Octocorallia, Alcyonacea, Nidaliidae), the first species of the genus discovered in the Mediterranean Sea. Mar. Biodiv. 45: 667-688. https://doi.org/10.1007/s12526-014-0269-5

Lumley L.M., Sperling F.A.H. 2010. Integrating morphology and mitochondrial DNA for species delimitation within the spruce budworm (Choristoneura fumiferana) cryptic species complex (Lepidoptera: Tortricidae). Syst. Entomol. 35: 416-428. https://doi.org/10.1111/j.1365-3113.2009.00514.x

McArdle B.H., Anderson M.J. 2001. Fitting multivariate models to community data: A comment on distance-based redundancy analysis. Ecol. Soc. Am. 82: 290-297.

https://doi.org/10.1890/0012-9658(2001)082[0290: fmmtcd $2.0 \cdot \operatorname{co}: 2$

McFadden C.S., Hutchinson M.B. 2004. Molecular evidence for the hybrid origin of species in the soft coral genus Alcyonium (Cnidaria: Anthozoa: Octocorallia). Mol. Ecol. 13: 1495-1505. https://doi.org/10.1111/j.1365-294X.2004.02167.x

McFadden C.S., van Ofwegen L.P. 2013. A second, cryptic species of the soft coral genus Incrustatus (Anthozoa: Octocorallia: Clavulariidae) from Tierra del Fuego, Argentina, revealed by DNA barcoding. Helgol. Mar. Res. 67: 137-147. https://doi.org/10.1007/s10152-012-0310-7

McFadden C.S., Tullis I.D., Hutchinson M.B., et al. 2004. Variation in coding (NADH dehydrogenase subunits 2, 3, and 6) and noncoding intergenic spacer regions of the mitochondrial genome in Octocorallia (Cnidaria: Anthozoa). Mar. Biotechnol. 6: 516-526. https://doi.org/10.1007/s10126-002-0102-1

McFadden C.S., France S.C., Sánchez J.A., et al. 2006. A molecular phylogenetic analysis of the Octocorallia (Cnidaria: Anthozoa) based on mitochondrial protein-coding sequences. Mol. Phylogenet. Evol. 41: 513-527. https://doi.org/10.1016/j.ympev.2006.06.010

McFadden C.S., Sánchez J.A., France S.C. 2010. Molecular phylogenetic insights into the evolution of octocorallia: A review. Integr. Comp. Biol. 50: 389-410. https://doi.org/10.1093/icb/icq056

McFadden C.S., Benayahu Y., Pante E., et al. 2011. Limitations of mitochondrial gene barcoding in Octocorallia. Mol. Ecol. Resour. 11: 19-31. https://doi.org/10.1111/j.1755-0998.2010.02875.x

Meyer C.P., Paulay G. 2005. DNA barcoding: Error rates based on comprehensive sampling. PLoS Biol. 3: 1-10. https://doi.org/10.1371/journal.pbio.0030422

Milne-Edwards H., Haime J. 1857. Histoire naturelle des coralliaires: ou, Polypes proprement dits. à la Libraire Encyclopédique de Roret, Paris.
Mutanen M., Pretorius E. 2007. Subjective visual evaluation vs. traditional and geometric morphometrics in species delimitation: A comparison of moth genitalia. Syst. Entomol. 32: 371-386. https://doi.org/10.1111/j.1365-3113.2006.00372.x

Nater A., Burri R., Kawakami T, et al. 2015. Resolving evolutionary relationships in closely related species with whole-genome sequencing data. Syst. Biol. 46: 1-54. https://doi.org/10.1093/sysbio/syv045

Padial J.M., Miralles A., de la Riva I., et al. 2010. The integrative future of taxonomy. Front. Zool. 7: 16. https://doi.org/10.1186/1742-9994-7-16

Pérez C.D., Neves B.M., Cordeiro R.T., et al. 2016. Diversity and Distribution of Octocorallia. In: Goffredo S., Dubinsky Z. (eds) The Cnidaria, Past, Present and Future. Springer International Publishing, Cham, pp 109-123. https://doi.org/10.1007/978-3-319-31305-4_8

Posada D. 2008. jModelTest: Phylogenetic model averaging. Mol. Biol. Evol. 25: 1253-1256. https://doi.org/10.1093/molbev/msn083

Rambaut A., Drummond A. 2007. Tracer v1.4 http://beast.bio.ed.ac.uk/Tracer

Rocha-Olivares A., Fleeger J.W., Foltz D.W. 2001. Decoupling of molecular and morphological evolution in deep lineages of a Meiobenthic harpacticoid copepod. Mol. Biol. Evol. 18: 1088-1102. https://doi.org/10.1093/oxfordjournals molbev a003880

Rossi S., Gili J.M., Garrofé X. 2011. Net negative growth detected in a population of Leptogorgia sarmentosa: quantifying the biomass loss in a benthic soft bottom-gravel gorgonian. Mar. Biol. 158: 1631-1643. https://doi.org/10.1007/s00227-011-1675-x

Sánchez J.A. 2009. Systematics of the candelabrum gorgonian corals (Eunicea Lamouroux; Plexauridae; Octocorallia; Cnidaria). Zool. J. Linn. Soc. 157: 237-263. https://doi.org/10.1111/j.1096-3642.2008.00515.x

Sánchez J.A., Wirshing H.H. 2005. A field key to the identification of tropical western Atlantic zooxanthellate octocorals (Octocorallia: Cnidaria). Caribb. J. Sci. 41: 508-522.

Sánchez J.A., McFadden C.S., France S.C., et al. 2003. Molecular phylogenetic analyses of shallow-water Caribbean octocorals. Mar. Biol. 142: 975-987. https://doi.org/10.1007/s00227-003-1018-7

Sánchez J.A., Aguilar C., Dorado D., et al. 2007. Phenotypic plasticity and morphological integration in a marine modular invertebrate. BMC Evol. Biol. 7: 122 https://doi.org/10.1186/1471-2148-7-122

Schwarzfeld M.D., Sperling F.A.H. 2014. Species delimitation using morphology, morphometrics, and molecules: Definition of the Ophion scutellaris Thomson species group, with descriptions of six new species (Hymenoptera, Ichneumonidae). Zookeys 114: 59-114. https://doi.org/10.3897/zookeys.462.8229

Soler-Hurtado M.M., López-González P.J. 2012. Two new gorgonian species (Anthozoa: Octocorallia: Gorgoniidae) from Ecuador (Eastern Pacific). Mar. Biol. Res. 8: 380-387. https://doi.org/10.1080/17451000.2011.634814

Soler-Hurtado M.M., López-González P.J., Muñoz J., et al. 2016. New records of the genera Leptogorgia, Pacifigorgia and Eugorgia (Octocorallia, Gorgoniidae) from Ecuador and description of a new species. Sci. Mar. 80: 369-394. https://doi.org/10.3989/scimar.04392.14A

Stefani F., Benzoni F., Pichon M., et al. 2008. A multidisciplinary approach to the definition of species boundaries in branching species of the coral genus Psammocora (Cnidaria, Scleractinia). Zool. Scr. 37: 71-91.

Strahler A.N. 1954. Quantitative geomorphology of erosional landscape. In: 19th Intern. Geol. Cong. Algiers, pp. 341-354.

Swofford D.L. 2003. PAUP*. Phylogenetic Analysis Using Parsimony (*and other methods), version 4. Sinauer Associates, Sunderland, Massachusetts.

Valenciennes A. 1846. Zoophytes. In: Dupetit-Thouars A. (ed) Voyage autour du monde sur la frégate la Vénus, pendant les années 1836-1839. Atlas de Zoologie. Publié par ordre Du Roi, Paris, pp. 1-15.

van Oppen M.J., McDonald B.J., Willis B., et al. 2001. The evolutionary history of the coral genus Acropora (Scleractinia, Cnidaria) based on a mitochondrial and a nuclear marker: reticulation, incomplete lineage sorting, or morphological convergence? Mol. Biol. Evol. 18: 1315-1329.

https://doi.org/10.1093/oxfordjournals.molbev.a003916 
van Velzen R., Weitschek E., Felici G., et al. 2012. DNA barcoding of recently diverged species: Relative performance of matching methods. PLoS One 7: e30490. https://doi.org/10.1371/journal.pone.0030490

Vargas S., Breedy O., Guzman H.M. 2010. The phylogeny of Pacifigorgia (Coelenterata, Octocorallia, Gorgoniidae): a case study of the use of continuous characters in the systematics of the Octocorallia. Zoosystema 32: 5-18. https://doi.org/10.5252/z2010n1a1

Vargas S., Guzman H.M., Breedy O., et al. 2014. Molecular phylogeny and DNA barcoding of tropical eastern Pacific shallowwater gorgonian octocorals. Mar. Biol. 161: 1027-1038. https://doi.org/10.1007/s00227-014-2396-8

Vermeij M.J.A., Sandin S.A., Samhouri J.F. 2007. Local habitat distribution determines the relative frequency and interbreeding potential for two Caribbean coral morphospecies. Evol. Ecol. 21: $27-47$. https://doi.org/10.1007/s10682-006-9122-Z

Verrill A.E. 1868. Notes on Radiata in the Museum of Yale College, Number 6, Second. Transactions of the Connecticut Academy of Arts and Sciences.

Viladrich N., Gori A., Gili J.M. 2016. Fast growth rate in a young colony of the Mediterranean gorgonian Eunicella singularis. Mar. Biodiv. 158: 1631-1643. https://doi.org/10.1007/s12526-016-0554-6

Vollmer S.V., Palumbi S.R. 2004. Testing the utility of internally transcribed spacer sequences in coral phylogenetics. Mol. Ecol. 13: $2763-2772$. https://doi.org/10.1111/j.1365-294X.2004.02265.x

Weinbauer M.G., Branko V. 1995. Morphological variations in the
Mediterranean sea fan Eunicella cavolini (Coelenterata: Gorgonacea) in relation to exposure, colony size and colony region. Bull. Mar. Sci. 56: 283-295.

Wiemers M., Fiedler K. 2007. Does the DNA barcoding gap exist? - a case study in blue butterflies (Lepidoptera: Lycaenidae). Front. Zool. 4: 8. https://doi.org/10.1186/1742-9994-4-8

Williams G.C., Lindo K.G. 1997. A review of the octocorallian genus Leptogorgia (Anthozoa: Gorgoniidae) in the Indian Ocean and Subantarctic, with description of a new species and comparisons with related taxa. Proc. Calif. Acad. Sci. 49: 499-521.

Williams G.C. Chen J.Y. 2012. Resurrection of the octocorallian genus Antillogorgia for Caribbean species previously assigned to Pseudopterogorgia, and a taxonomic assessment of the relationship of these genera with Leptogorgia (Cnidaria, Anthozoa, Gorgoniidae). Zootaxa 3505: 39-52.

Winkler I.S., Blaschke J.D., Davis D.J., et al. 2015. Explosive radiation or uninformative genes? Origin and early diversification of tachinid flies (Diptera: Tachinidae). Mol. Phylogenet. Evol. 88: $38-54$. https://doi.org/10.1016/j.ympev.2015.03.021

Wirshing H.H., Baker A.C. 2015. Molecular and morphological species boundaries in the gorgonian octocoral genus Pterogorgia (Octocorallia: Gorgoniidae). PLoS one 10: e0133517. https://doi.org/10.1371/journal.pone.0133517

Yasuda N., Taquet C., Nagai S., et al. 2015. Genetic diversity, paraphyly and incomplete lineage sorting of mtDNA, ITS2 and microsatellite flanking region in closely related Heliopora species (Octocorallia). Mol. Phylogenet. Evol. 93: 161-171. https://doi.org/10.1016/j.ympev.2015.07.009 